\title{
Grain yield, carbon isotope discrimination and mineral content in mature kernels of barley under irrigated and rainfed conditions
}

\author{
A Febrero $^{1 *}, \mathrm{~J}$ Bort $^{1}, \mathrm{~J}$ Català $^{1}, \mathrm{P}$ Marzabal $^{1}, \mathrm{~J}$ Voltas $^{2}, \mathrm{JL}$ Araus $^{1}$ \\ ${ }^{1}$ Departament de Biologia Vegetal, Facultat de Biologia, Universitat de Barcelona, \\ Avda Diagonal 645, E08028 Barcelona; \\ ${ }^{2}$ Departamento de Producción Vegetal, Centro UdL-IRTA, Avda Alcalde Rovira Roure, 177, E25006 Lerida, Spain
}

(Received 7 July 1993; accepted 6 December 1993)

\begin{abstract}
Summary - The relationship between yield, carbon isotope discrimination and ash content in mature kernels was examined for a set of 13 barley (Hordeum vulgare) cultivars. Plants were grown under rainfed and well-irrigated conditions in a Mediterranean area. Water deficit caused a decrease in both grain yield and carbon isotope discrimination $(\Delta)$. The yield was positively related to $\Delta$ and negatively related to ash content, across genotypes within each treatment. However, whereas the correlation between yield and $\Delta$ was higher for the set of genotypes under well-irrigated $(r=0.70, P<0.01)$ than under rainfed $(r=0.42)$ conditions, the opposite occurred when yield and ash content were related, ie $r=-0.38$ under well-irrigated and $r=-0.73$, $(P<0.01)$ under rainfed conditions. Carbon isotope discrimination and ash content together account for almost $60 \%$ of the variation in yield, in both conditions. There was no significant relationship $(r=-0.15)$ between carbon isotope discrimination and ash content in well-irrigated plants, whereas in rainfed plants, this relationship, although significant $(r=-0.54, P<0.05)$, was weakly negative. The concentration of several mineral elements was measured in the same kernels. The mineral that correlated best with ash content, yield and $\Delta$, was $\mathrm{K}$. For yield and $\Delta$, although the relationship with $\mathrm{K}$ followed the same pattern as the relationhip with ash content, the correlation coefficients were lower. Thus, mineral accumulation in mature kernels seems to be independent of transpiration efficiency. In fact, filling of grains takes place through the phloem pathway. The ash content in kernels is proposed as a complementary criterion, in addition to kernel $\Delta$, to assess genotype differences in barley grain yield under rainfed conditions.
\end{abstract}

yield/barley/kernel/mineral content/carbon isotope discrimination

Résumé - Rendement en grain, discrimination isotopique du carbone et teneur en minéraux dans les grains mûrs d'orge en conditions irriguée et non irriguée. La relation entre la production, la discrimination isotopique et le contenu en cendres dans les grains mûrs a été examinée dans 13 cultivars d'orge (Hordeum vulgare L). Les plantes ont été cultivées dans 2 conditions: I'une en déficit hydrique et l'autre en régime d'irrigation, en zone méditerranéenne. Le déficit hydrique a causé une diminution de la production et de la discrimination isotopique du carbone $(\Delta)$. La production a été positivement corrélée avec $\Delta$ et négativement avec le contenu en cendres, entre les génotypes de chaque traitement. Cependant, tandis que la corrélation entre la production et $\Delta$ a été plus haute dans l'ensemble des génotypes sous conditions d'irrigation $(\mathrm{r}=0,70 ; \mathrm{P}<0,01)$ que chez les non irrigués $(\mathrm{r}=0,42)$, le contraire se produit quand la production et le contenu en cendres sont mis en rapport $(\mathrm{r}=-0,38$ sous conditions d'irrigation et $\mathrm{r}=-0,73$, $(\mathrm{P}<0,01)$ sous conditions de sécheresse). La discrimination isotopique du carbone et le contenu en cendres expliquent ensemble environ $60 \%$ de la variation dans la production dans les 2 conditions. II n'y a pas eu de relation significative $(r=-0,15)$ entre la discrimination isotopique du carbone et le contenu en cendres

\footnotetext{
${ }^{*}$ Correspondence and reprints
} 
dans les plantes irriguées, tandis que dans les non irriguées, cette relation, bien qu'elle ait été significative $(r=-0,54 ; \mathrm{P}<0,05)$, a été faiblement négative. La concentration de quelques éléments minéraux a été mesurée dans les mêmes grains. Le minéral le mieux corrélé au contenu en cendres, à la production et à $\Delta$, a été le $K$. Pour la production et $\Delta$, bien que la relation en $K$ ait suivi le même schéma que la relation en contenu en cendres, les coefficients de corrélation sont plus bas. De cette façon, l'accumulation minérale dans les grains mûrs semble être indépendante de l'efficacité transpiratoire; en fait, le remplissage des grains a lieu à travers la voie du phloème. Le contenu en cendres des grains est proposé comme un critérium complémentaire, en plus du $\Delta$ des grains, pour fixer des différences génotypiques dans la production de grains d'orge en situation de déficit hydrique.

\section{production/orge/grains/contenu en minéraux/discrimination isotopique du carbone}

\section{INTRODUCTION}

Water-use efficiency (WUE), the ratio of $\mathrm{CO}_{2}$ fixed to $\mathrm{H}_{2} \mathrm{O}$ transpired, is an important plant attribute for growth in dry areas. Carbon isotope discrimination $(\Delta)$ is negatively correlated with WUE, and has thus been proposed as an integrated criterion for WUE selection in breeding programs for crop plants, since there is significant genetic variation in WUE within and between species (Farquhar and Richards, 1984; Farquhar et al, 1989).

Carbon isotope discrimination is positively correlated with intercellular $\mathrm{CO}_{2}$ concentration (Farquhar et al, 1989). At first, low $\Delta$ appears to be an advantageous trait, especially in water-stressed environments, as it indicates a high WUE. However, low $\Delta$ has been associated with low yield and waterstress susceptibility in wheat (Morgan et al, 1993) and barley (Romagosa and Araus, 1991). In fact, higher stomatal conductance appears to allow higher photosynthetic rates, even when WUE decreases (Austin, 1987) and thus improves yield. Moderate positive correlations between mean grain yield and mature grain $\Delta$ have been reported in the same genotypes (Romagosa and Araus, 1991; Araus et al, 1993) for a set of environments of differing water deficits, even in the most severe. The isotope composition of the kernel at maturity integrates the $\mathrm{C}$ from photosynthesis during grain filling with that stored before anthesis.

Alternatively, plant mineral content may be a useful (ie cheaper and easier to develop) criterion in selection programs to improve transpiration efficiency since its correlation with WUE has been reported to be not much lower than that of $\Delta$ (Masle et al, 1992). Thus, Masle et al (1992) found a negative relationship between WUE and ash content $\left(m_{\mathrm{a}}\right)$ and a positive correlation between $\Delta$ and $m_{\mathrm{a}}$, with- in leaf blades of species with $\mathrm{C}_{3}$ and $\mathrm{C}_{4}$ pathways of photosynthesis. However, no study has been reported with $m_{\mathrm{a}}$ of kernels, even though they are currently used more than leaves for studies relating $\Delta$ and yield in cereals.

Here we describe the relationship between total ash content or the content of different minerals in kernels and $\Delta$ of the same kernels or grain yield for a set of barley cultivars grown under Mediterranean conditions, with varying water regimes.

\section{MATERIALS AND METHODS}

Thirteen cultivars of barley (Hordeum vulgare L) were grown during the spring of 1990 in the experimental fields of the Faculty of Biology, University of Barcelona, Spain. The soil was a mollic xerofluvent with a sandy loam texture. The prevailing climate was Mediterranean. Plants were sown on January 24 at a seeding density of 250 seeds $\mathrm{m}^{-2}$. The experimental design consisted of a randomized block with 4 replicates per cultivar and water regime divided into 20 plots $(4.8 \times 2 \mathrm{~m})$, 4 genotypes per plot and 6 rows $(20 \mathrm{~cm}$ apart) per genotype. At planting plots received $8 \mathrm{~kg} \mathrm{~N} \mathrm{ha}^{-1}$ as granular $\mathrm{NH}_{4} \mathrm{NO}_{3}(33.5 \% \mathrm{~N})$ fertilizer, and $12 \mathrm{~kg}$ $\mathrm{N} \mathrm{ha}{ }^{-1}, 5.2 \mathrm{~kg} \mathrm{P} \mathrm{ha}^{-1}$ and $10 \mathrm{~kg} \mathrm{~K} \mathrm{ha}^{-1}$ in the form of a compound granular commercial fertilizer. Granular $\mathrm{NH}_{4} \mathrm{NO}_{3}(33.5 \% \mathrm{~N})$ fertilizer was additionally applied on March 2 and March 22, at the rate of $20 \mathrm{~kg} \mathrm{~N} \mathrm{ha}^{-1}$ each, resulting in a total of $60 \mathrm{~kg} \mathrm{~N} \mathrm{ha}{ }^{-1}$.

All genotypes were grown under 2 water conditions: (i) rainfed with limited irrigation at sowing time and in mid-February, following the first fertilization and thereafter only water from rainfall; and ii) regularly watered, to attain normal growth and development. Anthesis took place between mid-April and the first week of May. The grain yield at maturity was recorded.

Kernels used for stable ${ }^{13} \mathrm{C}$ isotope analysis were oven-dried and ground to a fine powder. The carbon isotope ratios $\left({ }^{13} \mathrm{C} /{ }^{12} \mathrm{C}\right)$ were determined by mass spectrometry by Isotope Services Inc, 
Los Alamos, NM, USA. Values were expressed as $\delta^{13} \mathrm{C}$ values, where:

$$
\delta^{13} \mathrm{C}(\%)=\left(R_{\text {sample }} / R_{\text {standard }}-1\right) \times 1000
$$

where $R$ is the ${ }^{13} \mathrm{C} /{ }^{12} \mathrm{C}$ ratio. The standard for comparison was a secondary standard calibrated against PeeDee belemnite (PDB) carbonate. Replicate samples differed by less than $0.10 \%$.

The value of the discrimination $(\Delta)$ againt ${ }^{13} \mathrm{C}$ was obtained from the isotope ratio, $\delta_{p}$, and $\delta_{a}$ (the carbon isotope composition of air, $-7.85 \%$ ):

$$
\Delta=\frac{\delta_{a}-\delta_{p}}{1+\delta_{p}}
$$

The ash content $\left(m_{\mathrm{a}}\right)$ in the powder was determined by burning it in a compact metallic block for digestion (RAIPA, SL, Spain, model MB-20) at $450^{\circ} \mathrm{C}$ for $8 \mathrm{~h}$ and weighing the residue. There were at least 3 replicates per cultivar sample, and approximately $3 \mathrm{~g}$ dry material was used per replicate. The ash content was expressed as a percentage of kernel dry weight. Nitric-perchloric (2:1) wet digestions were carried out on grain ash ( $3 \mathrm{ml}$ acid: $\sim 0.1 \mathrm{~g}$ ash) in an adapted microwave oven for $20 \mathrm{~min}$ at the highest power level $(1200 \mathrm{~W})$ to eliminate traces of organic matter. The ash was then dissolved in $25 \mathrm{ml}$ nitric acid ( $5 \%$ volume). Contents of $\mathrm{K}, \mathrm{Na}, \mathrm{Mn}, \mathrm{Mg}, \mathrm{Fe}, \mathrm{Ca}$ and $\mathrm{Zn}$ were later analyzed using inductively coupled plasma atomic emission spectroscopy (Polyscan 61E, Thermo Jarell Ash). Analyses were performed in the Servei d'Espectroscopia at the University of Barcelona. The values are means of 3 replicates per sample. Ion contents were expressed alternatively as ppm of dry weight (table I) or total content per kernel.

\section{RESULTS AND DISCUSSION}

A weak $(p<0.1)$ negative correlation was found between $\Delta$ and $m_{\mathrm{a}}$ in mature kernels for the rainfed treatment. No relationship was observed between the 2 parameters for the irrigated treatment (fig 1). Previous studies (Masle et al, 1992) reported a positive correlation between $m_{\mathrm{a}}$ and $\Delta$ in leaf dry matter. These different results suggest that mineral accumulation in the kernels is primarily regulated by a process other than transpiration and efficiency in the use of water.

The lack of a relationship between $\Delta$ and $m_{\mathrm{a}}$ under well-irrigated and rainfed conditions strongly suggests that mineral accumulation in mature kernels is insensitive to environmental changes that affect the transpirational stream, and thus the passive accumulation of mineral elements or WUE. Present results suggest that, in contrast to that reported for $\Delta$ of kernels (Condon et al, 1900; Morgan et

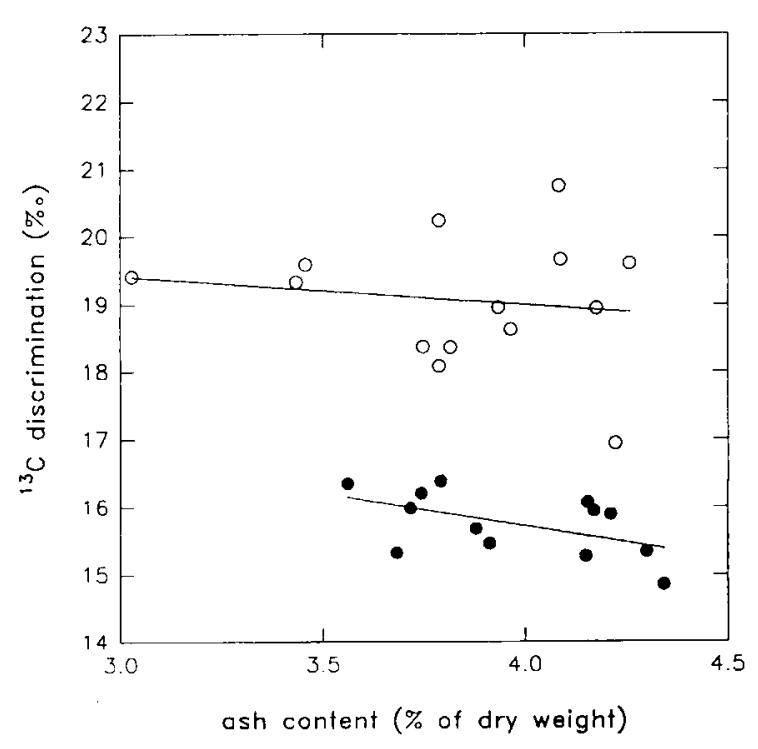

Fig 1. Relationship between ash content, per unit dry matter, and carbon isotope discrimination in mature kernels for a set of 13 barley genotypes grown under irrigated $\left(O, r^{2}=0.0221\right)$ and rainfed $\left(0, r^{2}=0.2922\right)$ Mediterranean conditions.

al, 1993), mineral accumulation in the kernel is not related to the integrated WUE of the plant during the grain-filling period. In fact, minerals accumulate in kernels by phloem transport rather than passively from the transpiration stream. Walker and Lance (1991) reported that silicon concentration in plant (not kernel) samples of a set of barley cultivars correlated with $\Delta$ positively and more strongly in the field than in the glasshouse experiments, in which a weak negative correlation between parameters was observed. These authors suggested that, under mild glasshouse conditions, plants actively accumulate Si whereas, under higher evaporative demand in the field, Si accumulates passively by the transpirational stream.

Yield was negatively $(p<0.05)$ related to $m_{\mathrm{a}}$ in the rainfed treatment (fig 2). The negative relationship was not significant in the irrigated treatment. Of the mineral elements assayed (table $\mathrm{I}$ ), the concentration of $\mathrm{K}$ per kernel dry matter best correlated with total kernel ash content, yield and $\Delta$ (table II). However, for yield and $\Delta$, the relationship with $\mathrm{K}$ followed the same pattern as the relationship with ash content, but the correlation coefficients were lower.

The accumulation of carbohydrates in the grain depends on the photosynthetic rates during grain filling and on pre-anthesis storage, mainly in the internodes. On the other hand, mineral accumulation in the kernel de- 


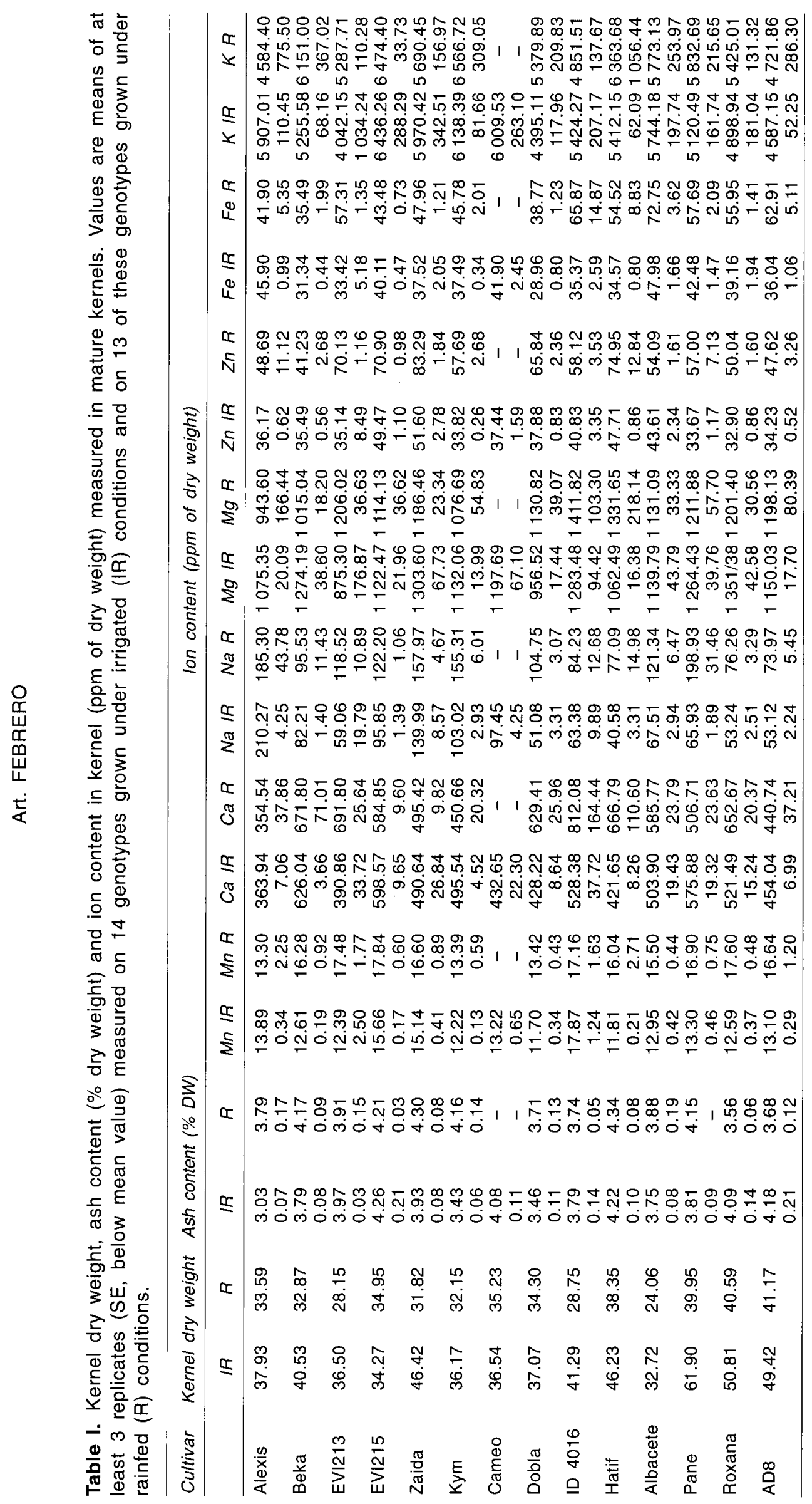




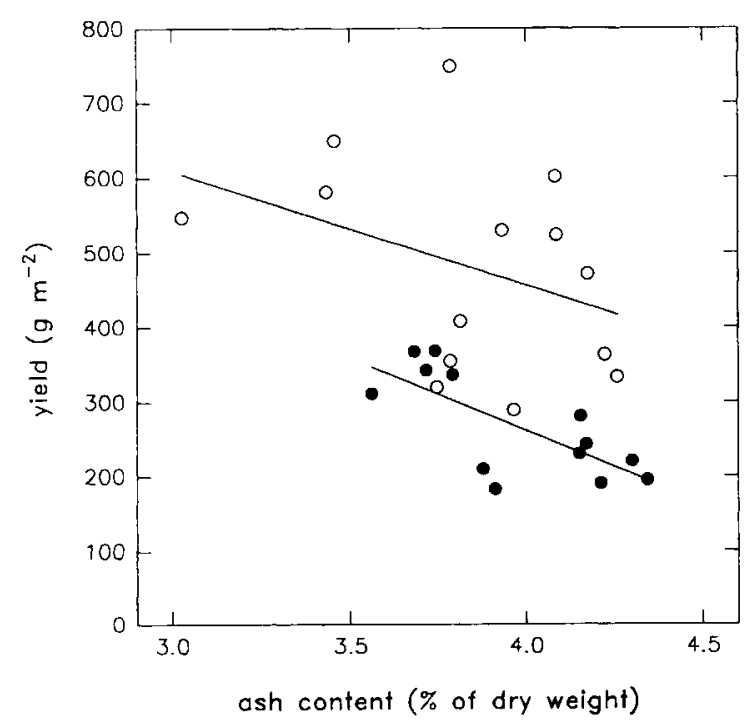

Fig 2. Relationship between ash content in mature kernels and grain yield for the set of genotypes and growth conditions shown in figure 1 (irrigated $O, r^{2}=0.1448$; rainfed $\bullet, r^{2}=0.5403$ ).

pends on current photosynthesis by the ear, translocation from the leaves, and also on minerals removed from the lower part of the plant after the onset of senescence (Wardlaw, 1990). Under rainfed conditions, photosynthesis is more restricted than translocation and the proportion of minerals to carbohydrates in kernels rises (see horizontal axis in figure 1) although the correlation with final kernel size may be lower. This is shown by the coefficient of determination of the relationship between the kernel dry weight and the absolute ash content per kernel, which was higher for the irrigated treatment $\left(r^{2}=0.87\right.$; solid line in figure 3 ) than for the rainfed treatment $\left(r^{2}\right.$ $=0.57$; dotted line in figure 3 ). Similar differences between irrigated and rainfed conditions were found for the set of mineral elements studied (table III). In our study almost $60 \%$ of the variation in grain yield, in

Table II. Values of $r^{2}$ for correlations between $K$ content per unit dry weight and total ash content, yield or carbon isotope discrimination $(\Delta)$.

\begin{tabular}{lccc}
\hline & $\begin{array}{c}\text { Total ash } \\
\text { content } \\
D W^{-1}\end{array}$ & Yield & $\Delta$ \\
\hline K IR & 0.021 & 0.001 & 0.009 \\
K R & 0.591 & 0.465 & 0.070 \\
\hline
\end{tabular}

Correlations were performed using 13 genotypes, under either irrigated (IR) or rainfed ( $R$ ) conditions. $K$, total mineral content and $\Delta$ were measured in mature kernels.

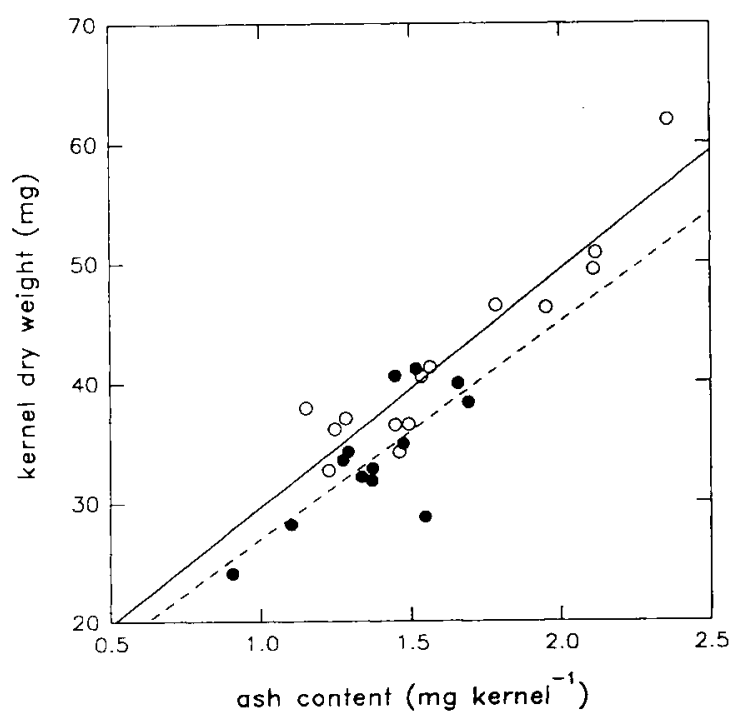

Fig 3. Relationship between ash content per kernel and kernel dry weight. The solid line corresponds to the linear regression fitted for irrigation treatment $\left(O, r_{2}=0.8712\right)$ and the dotted line corresponds to the rainfed treatment $\left(0, r^{2}=0.5736\right)$.

both the irrigated and the rain-fed treatments, was explained by kernel $\Delta$ and $m_{\mathrm{a}}$ together (table IV). Taken together, these results suggest that the sources of dry matter for the kernel are differently affected by the water treatment. Under irrigation, the supply of carbohydrates to the kernel is enhanced by a longer grain-filling period, whereas under a shortage of water, the shorter photosynthetically active period brings about an increase in the mineral to carbohydrate ratio, as observed above.

Table III. Values of $r^{2}$ of the correlations between amount of mineral per kernel and total ash content per kernel.

\begin{tabular}{lll}
\hline \multirow{2}{*}{ Mineral } & \multicolumn{2}{c}{ Total ash content } \\
\cline { 2 - 3 } & \multicolumn{1}{c}{$I R$} & \multicolumn{1}{c}{$R$} \\
\hline $\mathrm{Mg}$ & $0.773^{\star \star}$ & $0.746^{\star \star}$ \\
$\mathrm{Zn}$ & 0.468 & 0.331 \\
$\mathrm{Fe}$ & $0.555^{\star}$ & 0.242 \\
$\mathrm{~K}$ & $0.507^{*}$ & 0.471 \\
$\mathrm{Mn}$ & $0.590^{*}$ & 0.550 \\
$\mathrm{Ca}$ & $0.666^{\star}$ & 0.285 \\
$\mathrm{Na}$ & 0.020 & 0.037 \\
\hline
\end{tabular}

Correlations were performed using 13 genotypes, under either irrigated (IR) or rainfed (R) conditions. Total ash content and total mineral content were measured in mature kernels. ${ }^{\star} p<0.05 ;{ }^{* \star} p<0.01$. 
Table IV. Percentage of yield variation among genotypes explained by carbon isotope discrimination and ash content ( $\%$ dry weight).

\begin{tabular}{lcc}
\hline & Irrigated & Rainfed \\
\hline $\begin{array}{l}\text { Carbon isotope } \\
\text { discrimination }(\%)\end{array}$ & 48.75 & 17.71 \\
$\begin{array}{l}\text { Carbon isotope discrimina- } \\
\text { tion + ash content }(\%)\end{array}$ & 56.57 & 56.68 \\
\hline
\end{tabular}

Calculations were performed by fitting a multilinear regression model using PC-NCSS.

These results suggest that $m_{\mathrm{a}}$ from kernels may be considered as a complementary criterion to assess genotype differences in cereal grain yield, particularly under rainfed conditions.

\section{ACKNOWLEDGMENTS}

We thank Dr M Ballcells and $\mathrm{Dr} M$ Roure at the Servei d'Espectroscopia, Universitat de Barcelona for technical assistance in the analysis of mineral elements. This work was supported in part by the Research Project of CICYT AGF92-0301, Spain.

\section{REFERENCES}

Araus JL, Febrero A, Bort J, Santiveri P, Romagosa I (1993) Carbon isotope discrimination, water-use efficiency and yield in cereals: some case studies. In: Tolérance à la sécheresse des céréales en zone méditerranéenne. Les Colloques $n^{\circ} 64$, Éd INRA, Paris 47-60
Austin RB (1987) Some crop characteristics of wheat and their influence on yield and water use. In: Drought Tolerance in Winter Cereals. (JP Srivastava, E Porceddu, E Acevedo, S Varma, eds) John Wiley \& Sons, Chichester, pp 321-336

Condon AG, Farquhar GD, Richards RA (1990) Genotypic variation in carbon isotope discrimination and transpiration efficiency in wheat. Leaf gas exchange and whole plant studies. Aust J Plant Physiol 17, 9-22

Farquhar GD, Richards RA (1984) Isotopic composition of plant carbon correlates with wateruse efficiency of wheat genotypes. Aust J Plant Physiol 11, 539-552

Farquhar GD, Ehleringer JR, Hubick KT (1989) Carbon isotope discrimination and photosynthesis. Ann Rev Plant Physiol Plant Mol Biol $40,503-537$

Masle J, Farquhar GD, Wong SC (1992) Transpiration ratio and plant mineral content are related among genotypes of a range of species. Aust $J$ Plant Physiol 19, 709-721

Morgan JA, LeCain DR, McCaig TN, Quick JS (1993) Gas exchange, carbon isotope discrimination and productivity in winter wheat. Crop Sci 33, 178-185

Romagosa I, Araus JL (1991) Genotype-environment interaction for grain yield and ${ }^{13} \mathrm{C}$ discrimination in barley. Barley Genetics VI, 563-567

Wardlaw IF (1990) Tansley Review No 27. The control of carbon partitioning in plants. New Phytol 116, 341-381

Walker CD, Lance RCM (1991) Silicon accumulation and ${ }^{13} \mathrm{C}$ composition as indices of wateruse efficiency in barley cultivars. Aust $J$ Plant Physiol 18, 427-434 